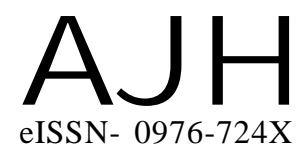

Received : 05.08.2015

Revised : 27.10 .2015

Accepted : 11.11.2015

Members of the Research Forum

Associated Authors:

${ }^{1}$ Department of Horticulture, Sardar

Vallabhbhai Patel University of

Agriculture and Technology,

MEERUT (U.P.) INDIA
Author for correspondence : YOGESH PRASAD RAJBHAR

Department of Horticulture, Sardar

Vallabhbhai Patel University of

Agriculture and Technology,

MEERUT (U.P.) INDIA

Email : rajbhar.yogesh@gmail.com
THEASIAN JOURNAL OF HORTICULTURE

Volume 10 | Issue 2 | December, 2015 | 222-231

Visit us -www.researchjournal.co.in

\section{Studies on the effect of growth regulator and vermicompost on growth and yield of different cultivars of strawberry (Fragaria $x$ ananassa Duch)}

\author{
YOGESH PRASAD RAJBHAR, BHAGAT SINGH ${ }^{1}$, GOPAL SINGH ${ }^{1}$, D.K. \\ SINGH $^{1}$ AND MUKESH KUMAR ${ }^{1}$
}

ABSTRACT : The present investigation was carried out at the Horticulture Research Center, of the SardarVallabhbhai Patel University of Agriculture and Technology, Meerut during 20132014.The maximum number of fruits (20.85) were recorded in the variety Chandler which was significantly superior to the rest of the varieties and followed by Gorella,Selva and Confictura.The maximum fruit yield per plant $(385.57 \mathrm{~g}$ ) was recorded in the variety Chandler which was superior to the rest of the varieties and was followed by Selva, Confictura and Douglas. The minimum fruit yield per plant $(177.79 \mathrm{~g})$ was noted in Gorella variety.The maximum fruit weight $(18.41 \mathrm{~g})$ was recorded in the variety Chandler which was significantly superior to the rest and followed by Confictura, Selva and Douglas. Application of gibberellic acid $\left(\mathrm{GA}_{3}\right) 100 \mathrm{ppm}+$ vermicompost @ 100q/ha was found to be the best treatment in response to fruit weight among different varieties of strawberry and recorded $16.48 \mathrm{~g}$. The maximum fruit yield $(171.36 \mathrm{q} / \mathrm{ha})$ was recorded in the variety Chandler which was significantly superior to the rest and was followed by Selva, Confictura and Douglas; however, Selva and Confictura were statistically at par to each other. Variety Chandler responded maximum effect on fruit yield per hectare i.e. $205.357 \mathrm{q} / \mathrm{ha}$ with the spray of gibberellic acid $\left(\mathrm{GA}_{3}\right) 100 \mathrm{ppm}$ and application of vermicompost @ 100q/ha. The maximum total soluble soilds $\left(10.68^{\circ} \mathrm{Brix}\right)$ was recorded in the variety Douglas which was superior to the rest and was followed by Confictura, Selva and Gorella. The minimum TSS value $\left(9.41^{\circ} \mathrm{Brix}\right)$ was noted in Chandler variety. Douglas responded maximum effect on TSS value i.e. $11.50^{\circ} \mathrm{Brix}$ with the spray of gibberellic acid $\left(\mathrm{GA}_{3}\right) 100$ ppm and application of vermicompost @ 100q/ha as basal dose which was statistically significant to other treatments and followed by Confictura, Selva and Gorella. Viewing the above observations, Chandler, Confictura and selva were found promising for commercial cultivation, however, Gorella was found to be earliest among all.

KEY WORDS : Growth regulator, Vermicompost, Growth, Yield, Cultivars

HOW TO CITE THIS ARTICLE : Rajbhar, Yogesh Prasad, Singh, Bhagat, Singh, Gopal, Singh, D.K. and Kumar, Mukesh (2015). Studies on the effect of growth regulator and vermicompost on growth and yield of different cultivars of strawberry (Fragaria x ananassa Duch). Asian J. Hort., 10(2) : 222-231. 